\title{
積層基板型小型コイルを用いたエネルギーハーベスタの研究
}

鈴木 洋一朗*1,*2, 桑野 博喜*3

\section{Study of energy harvester consisting of a laminated substrate integrated with thin film coil}

\author{
Youichirou SUZUKI ${ }^{* 1, * 2}$ and Hiroki KUWANO ${ }^{* 3}$ \\ ${ }^{* 1}$ NIPPON SOKEN, INC. \\ 14 Iwaya, Shimohasumi-cho, Nishio-shi, Aichi 445-0012, Japan \\ ${ }_{2,23}^{* 3}$ Department of Nanomechanics, School of Engineering, Tohoku University \\ 6-6-01 Aza-Aoba, Aramaki, Aoba-ku, Sendai-shi, Miyagi 980-8579, Japan
}

Received: 25 July 2016; Revised: 7 October 2016; Accepted: 29 January 2017

\begin{abstract}
We develop a laminated substrate integrated with thin film coil for application of an electromagnetic induction type energy harvester. Magnet material component is built-in in the center of coil as magnetic core. We verified that electric power that can be applied to the tire pressure monitor is obtained with the prototype.
\end{abstract}

Key words : Laminated substrate, Energy harvester, Vibration power generation device, Electromagnetic induction, Car electronics

\section{1. 緒 言}

現在の自動車においては，電子化の進展に伴い，あらゆる情報をセンシングし高度な制御に適用することで然 費向上や予防安全など自動車の高機能化を図っている．車両に搭載されるセンサ，アクチュエータ，それらを制 御する ECU（Electronic Control Unit）と呼ばれるマイコンの数は年々増大傾向にあり，現在，高級車では 100 を 超えるECU が搭載されている。これらセンサ，アクチュエータ，ECU はワイヤーハーネスで接続された有線ネ ットワークでデータ通信および電力供給されている，そのため，車両に搭載されるワイヤーハーネスの数も増大 の一途であり，例えばある車種では 1 台あたりのワイヤーハーネスが約 2000 本，重量にして約 $20 \mathrm{~kg}$ にまで増加 している．したがって，搭載スペース確保が困難であることや，重量増大による燃費悪化につながるという課題 がある.

このような課題を解決する技術として,近年注目を浴びているエネルギーハーベスティング技術が挙げられる. 環境に存在する熱や振動，光，電磁波などのエネルギーを回収し，電力に変換して使用する技術であるが，車両 内に存在する振動エネルギーなどから発電し，電力利用することで，有線での電源供給が不要となるため，増大 するワイヤーハーネスを削減，軽量化し，自動車の省燃費に貢献できる．車両の重量が $100 \mathrm{~kg}$ で約 $1 \mathrm{~km} / 1$ 燃費が 変わるといった試算もあり，ワイヤーハーネス削減の省然費への影響は少なくないと言える.

また，例えばタイヤ内など，電源供給が困難な場所へもセンサや無線機の搭載が可能になる．現在，タイヤ 空気圧モニタリングシステムと呼ばれるシステムが車両に搭載され，市販されている．タイヤ空気圧とタイヤ内 温度をセンシングし，無線通信で車両に通信寸ることで，空気圧低下や温度上昇など異常が発生した時にドライ

No.16-00328 [DOI:10.1299/transjsme.16-00328], J-STAGE Advance Publication date: 6 February, 2017

*1 正員, （株）日本自動車部品総合研究所（广445-0012 愛知県西尾市下羽角町岩谷 14）

*2 正員, 東北大学大学院工学研究科（T980-8579 宮城県仙台市青葉区荒巻字青葉 6-6-01）

*3 正員, フェロー，東北大学大学院工学研究科

E-mail of corresponding author: youichirou_suzuki@soken1.denso.co.jp

[DOI: 10.1299/transjsme.16-00328] 
バーに知らせるシステムである. タイヤホイール内のエアバルブ部に搭載されており，コイン電池により電源供 給するシステムであるが，コイン電池の電池容量からセンシング間隔が制約を受けており，エネルギーハーベス ティング技術を適用できれば，より細かなセンシングやデータ通信が可能となる. さらに，近年，次世代のタイ ヤ空気圧モニタリングシステムとして，タイヤトレッド裏面にセンサを直接貼り付けるタイプ (花塚他, 2012)

（Morinaga et al., 2010）（Morinaga et al., 2006）も研究開発が進められている. 路面からのダイレクトな振動が得 られるため, より高い振動エネルギーを取込み発電一の期待も高まっている.

環境に存在する各種エネルギー源を利用した発電技術は各々研究開発が進んでおり，適用するアプリケーショ ンに対して最良のエネルギー源を選択していくことが必要となる．車両へのエネルギーハーベスティング技術適 用において，振動エネルギーは，走行中であれば車両内の場所を選ばず，どの搭載位置においても，常時安定的 にエネルギーが得られることが最大の長所であり，我々は車両に適用するエネルギー源として，振動エネルギー に着目した。

また，振動発電の方式においても各種方式が存在するが，我々は，自動車の振動周波数としておよそ $300 \mathrm{~Hz}$ 以 下の比較的低周波振動から発電量が期待でき，且つ量産性を見据えた時に安価な構成で実現できる電磁誘導方式 に着目し, 発電素子の小型化における課題解決を目指した。電磁誘導方式の構造において, 特にコイル部分の寸 法が大きくなることで発電素子自体が大型化することが課題の一つに挙げられる.

本研究では, 電磁誘導式振動発電素子の小型化を実現する上で必須となる小型コイルの実現を目指した. 我々 は, 熱可塑性樹脂でできた低誘電率, 低誘電損失の極薄基板（片岡他, 2005）(Hayashi et al., 2004）(矢崎他, 2005） を用いて，積層基板構造を利用した小型コイルを提案している（図 1）（鈴木他，2015）。基板厚みは，1 層が 50 $\mu \mathrm{m}$ と極薄であること，また，基板製造工程において基板内に回路部品を内蔵実装できるといった特長を備えて おり, 磁性体を基板内部に内蔵実装した小型コイルを, 量産に適した低コストな製造方法にて実現が可能となる.

我々は，磁性体を内蔵実装した積層基板型の小型コイルを適用した電磁誘導式発電素子をサンプル試作し，タ イヤ空気圧モニタの電源適用を想定したタイヤ振動模擬実験から試作品の発電量を検証し, タイヤ空気圧モニタ を動作可能(約 1 分で無線機を動作可能)な電力が得られることを検証した.

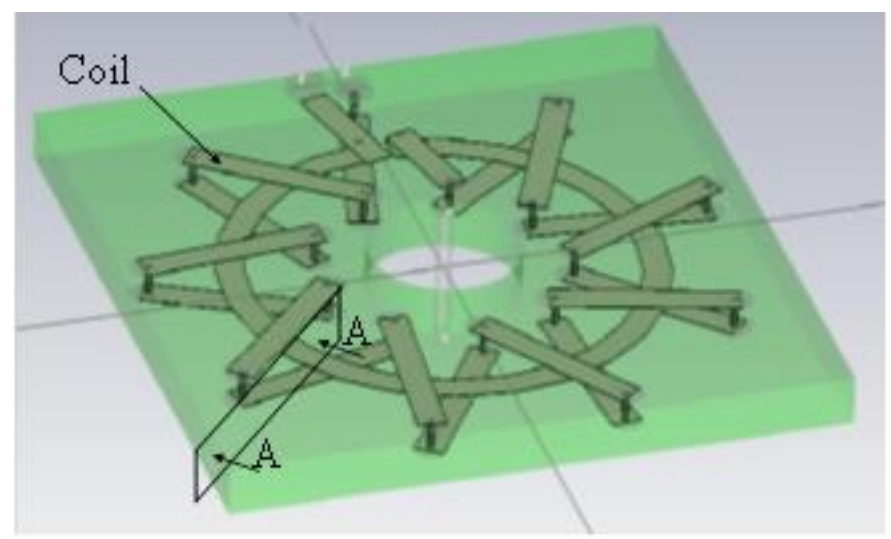

(a) Whole structure

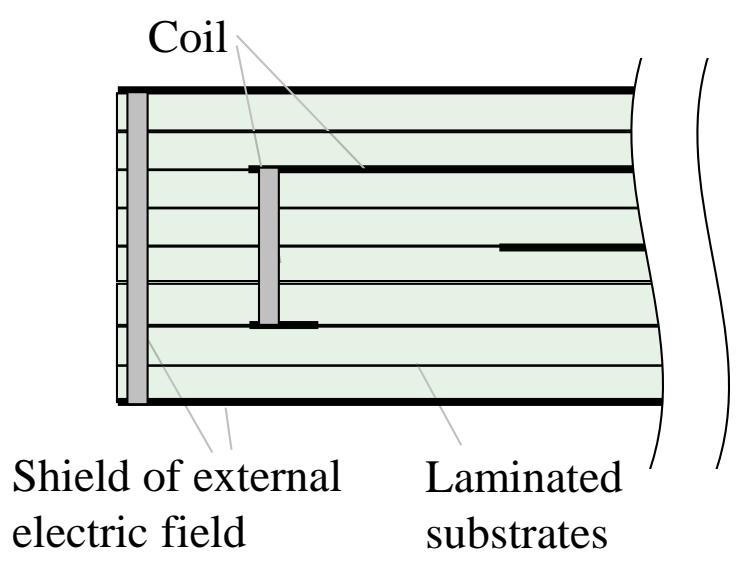

(b) A-A cross section

Fig. 1 The structure of laminated substrates type coil. 


\section{2. 振動発電素子の構造と原理}

我々が提案する電磁誘導式の発電素子構造を図 2 に示す. 振動部は一般的なカンチレバー方式を適用しており, 外部振動によって梁が変位する構造となる，また，将来的にはこのカンチレバー上に圧電膜を成膜すれば圧電方 式と電磁誘導方式のハイブリッド型でさらに電力の向上が期待できる構造となる．このカンチレバーの先には磁 石を搭載しており,外部振動によって上下にある積層基板型コイル内の磁性体と磁石が接触する構造を提案する. 磁性体と磁石が接触することで閉磁路が形成され，また，磁性体と磁石が離れることで開磁路に切替わる．した がって, 開磁路と閉磁路が外部振動によって切替わることで, 積層基板型コイルの内部を通る磁束に変化が起こ り，外部振動に起因する起電力が得られる構造となる，なお，外部振動によって得られる起電力はコイルの巻き 数とコイル内部を通る磁束の時間変化に比例して得られる. 本研究の試作品においては, 磁石にネオジウム磁石 (磁化の向きは第 3 章の図 3 記載), 磁性体にアモルファスダストを適用し, 磁性体の周りに巻き数 30 ターンの コイルを形成している. またカンチレバーの梁には樹脂基板を適用している.

また, 発電した電力を IC や無線機の電力として供給するためには, 発電素子の出力段に整流回路および蓄電 回路が必要となるが, 本研究で使用寸る熱可塑性樹脂基板では, 回路部品を内蔵実装できるため, 上記出力段の 回路部分も含めた小型化が可能となる.

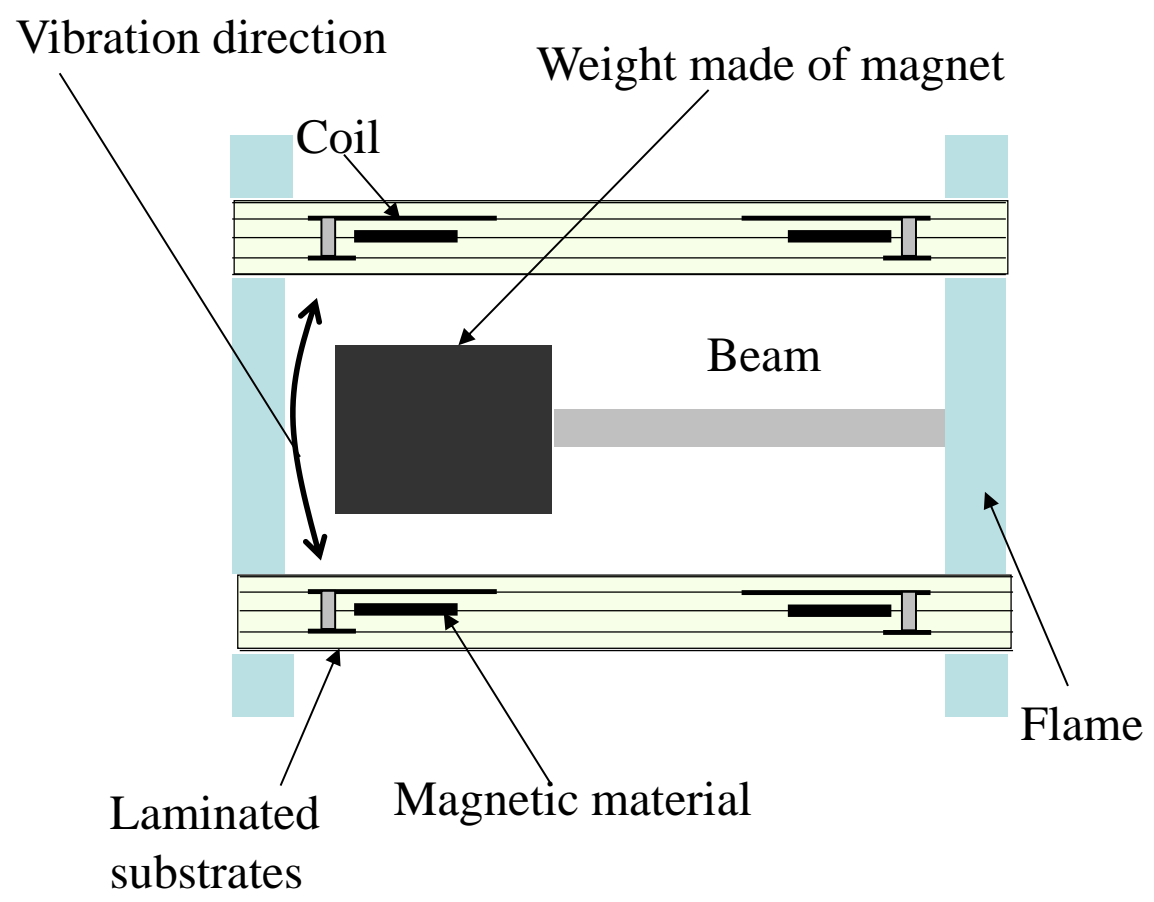

Fig.2. The cross section view of vibration energy harvester applying laminated substrates type coil.

\section{3. 電磁誘導発電のシミュレーション検討}

図 2 の電磁誘導式発電素子において, 効率よく出力を得るためには, 磁石と磁性体が接触した時の磁束と, 磁 石と磁性体が離れた時の磁束の差を最大限稼ぐことが必要となる．磁石と磁性体が接触した時には，磁性体の飽 和磁束密度に近い磁束を確保し，一方で磁石と磁性体が離れた時には磁束が 0 に近い值となることが望ましい. 
効率よく発電させるための暫定指標として, 磁石と磁性体が接触した時の磁束に対し, 1 割以下の磁束まで減少 させるために必要な磁石と磁性体の距離を見積り, 発電素子の構造(磁石と磁性体とのクリアランス)に反映して いく．外部振動によって磁石と磁性体の距離が変化することを想定し, 磁性体内部に発生する磁束の変化を静磁 場シミュレーション(ANSYS Maxwell を使用)にて検討した.

シミュレーション構造を図 3 に示す. コイル内に内蔵する磁性体部品（比透磁率：1000, 飽和磁束密度 : $2.5 \mathrm{~T}$ ) と磁石部品（ネオジム磁石）を抽出したシミュレーションモデルとし，磁性体と磁石の距離を変化させた時の磁 性体内部に発生する磁束密度をシミュレートした. 図4にシミュレーションより得られた, 磁石と磁性体の距離 に対する磁性体内部の磁束の変化を示す. 磁石と磁性体が接触（距離が $0 \mathrm{~mm} ）$ しいるときの磁束を 1 として規 格化したときの磁束の変化を示しており, 磁石と磁性体の距離が $4 \mathrm{~mm}$ まで離れることで, 磁性体内部の磁束す なわちコイル内部を通る磁束は, 接触時の 1 割以下まで減少する. 図 5 に, 磁石と磁性体とが接触 (距離が $0 \mathrm{~mm}$ ) の時, および磁石と磁性体との距離が $4 \mathrm{~mm}$ の時の静磁場シミュレーション結果を示す.いずれの結果において も磁性体内部を通る磁束が支配的であり, その磁束密度は, 磁石と磁性体が接触しているときは $2.1 \mathrm{~T}($ 磁性体断面 の中央部の值)であるのに対して, 磁石と磁性体の距離が $4 \mathrm{~mm}$ の時は $0.19 \mathrm{~T}$ (磁性体断面の中央部の值) と, 接触時 の 1 割以下まで減少している. したがって, 発電素子構造において, 磁石と磁性体とのクリアランスは $4 \mathrm{~mm}$ 以 上確保する構造とする，なお，試作品の発電素子構造においては，コイル基板全体のサイズを $18 \mathrm{~mm} \times 18 \mathrm{~mm} \times$ $2 \mathrm{~mm}$ (厚み), ビームやフレーム等含めた全体サイズを $30 \mathrm{~mm} \times 25 \mathrm{~mm} \times 15 \mathrm{~mm}$ (高さ)で組付けている.
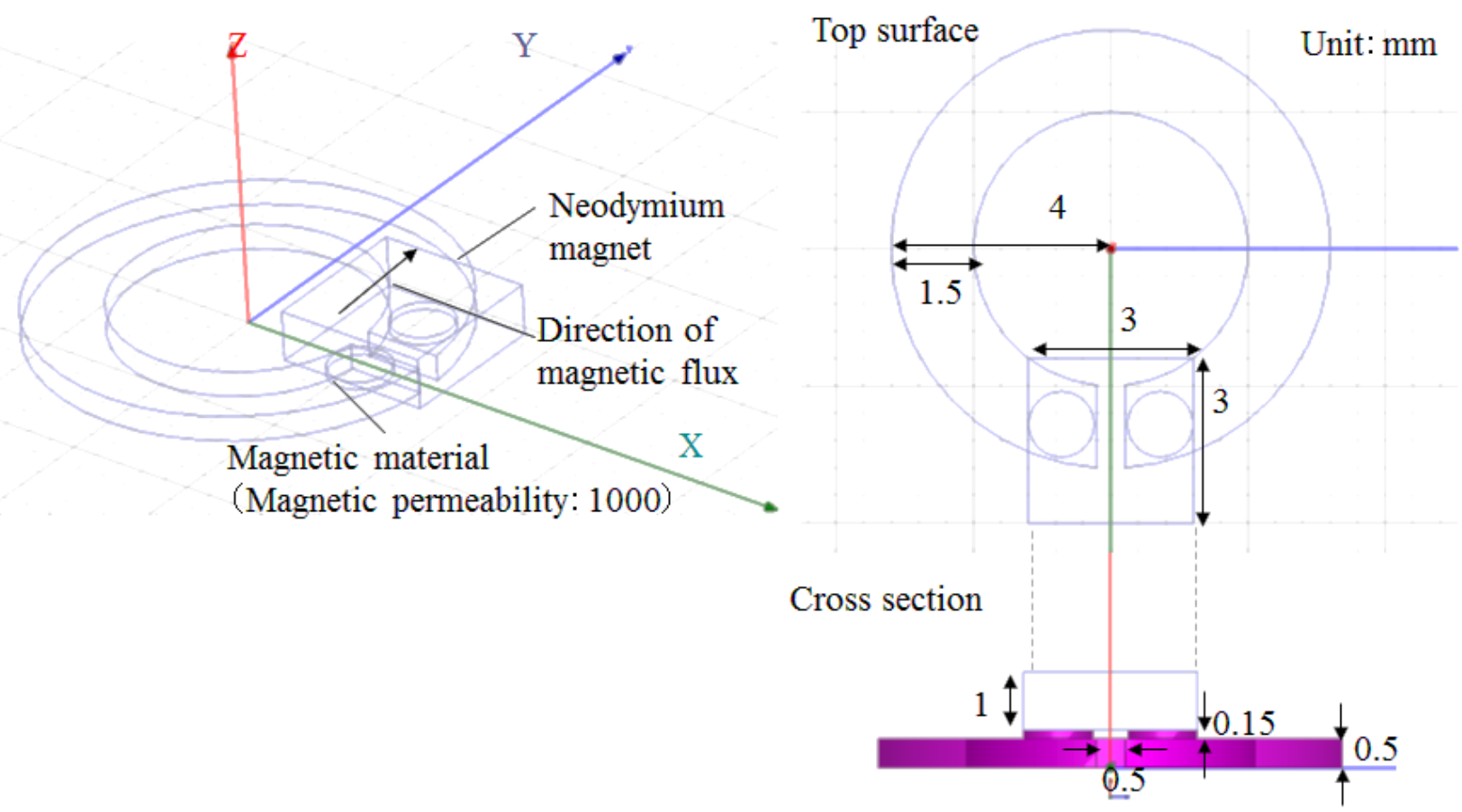

Fig.3 The structure of static magnetic field simulation. 
Suzuki and Kuwano, Transactions of the JSME (in Japanese), Vol.83, No.846 (2017)

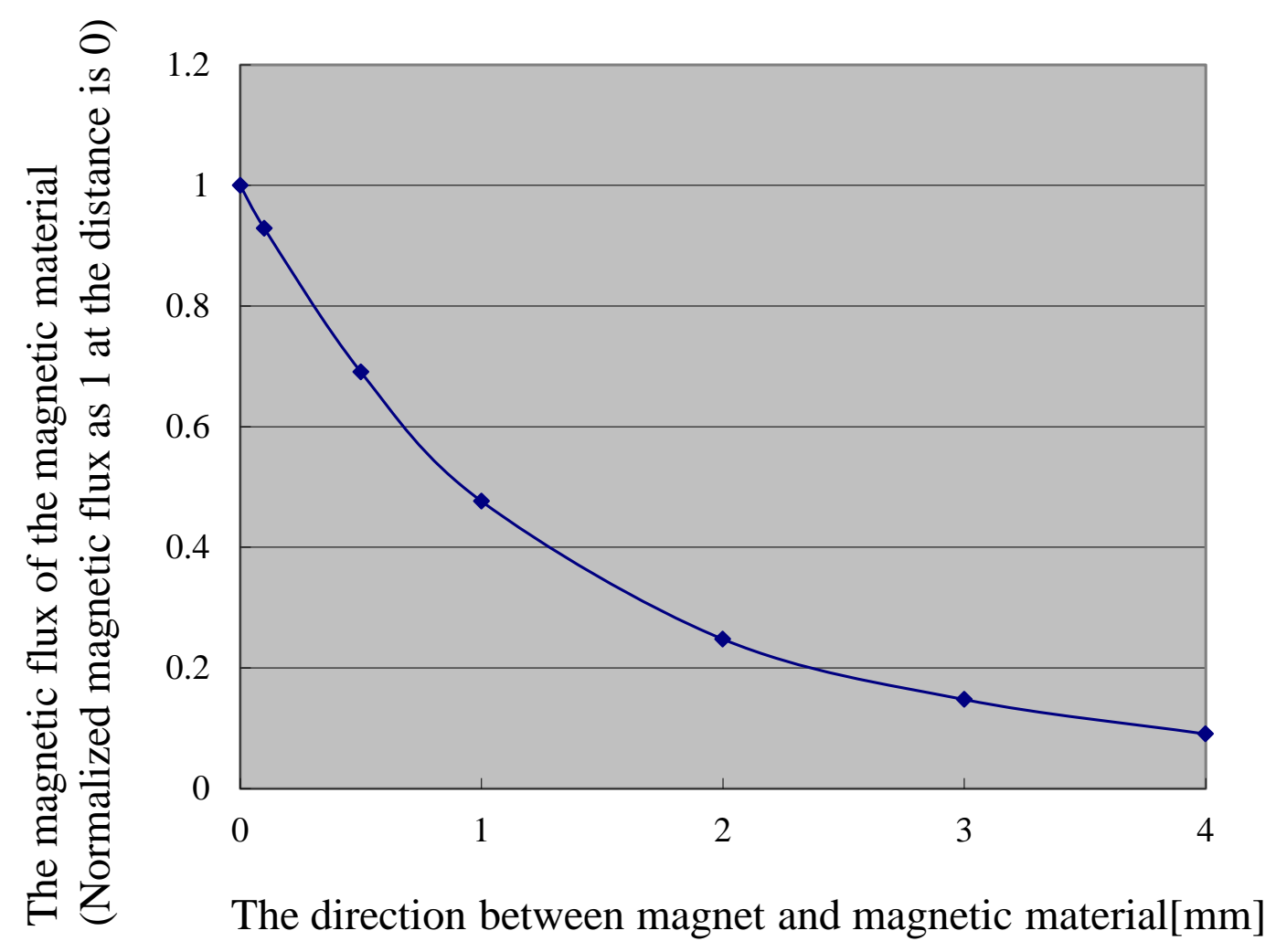

Fig.4 The change of magnetic flux against the distance between magnet and magnetic material. 

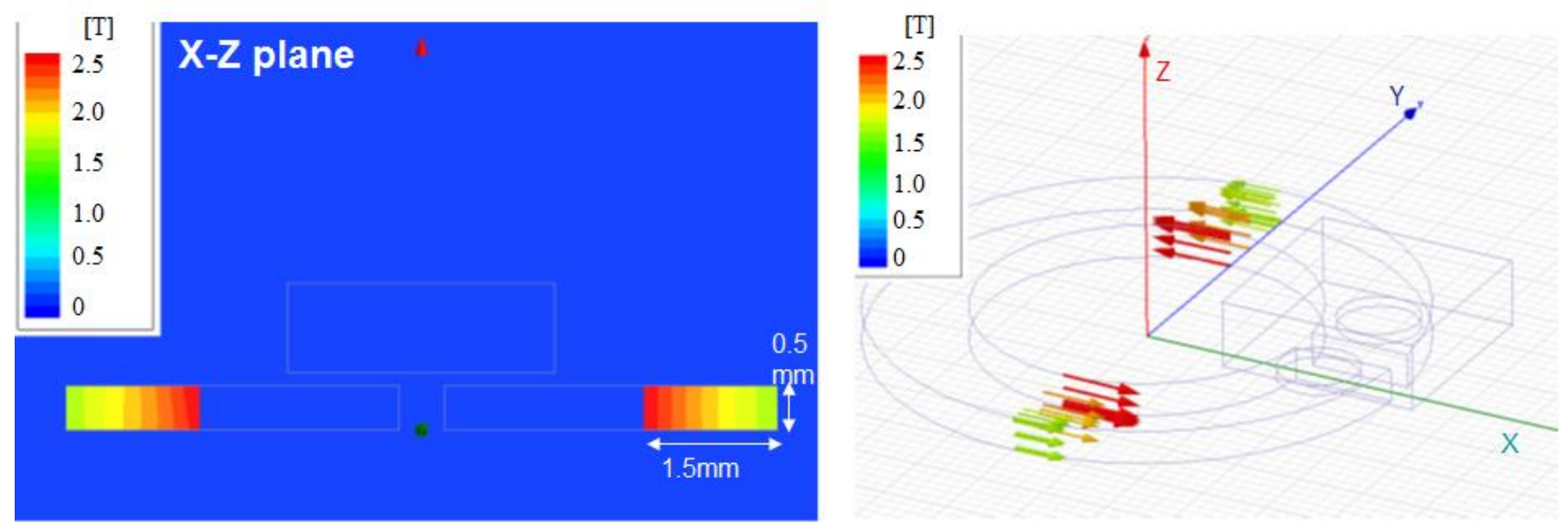

(a) The distance between magnetic material and magnet is $0 \mathrm{~mm}$.
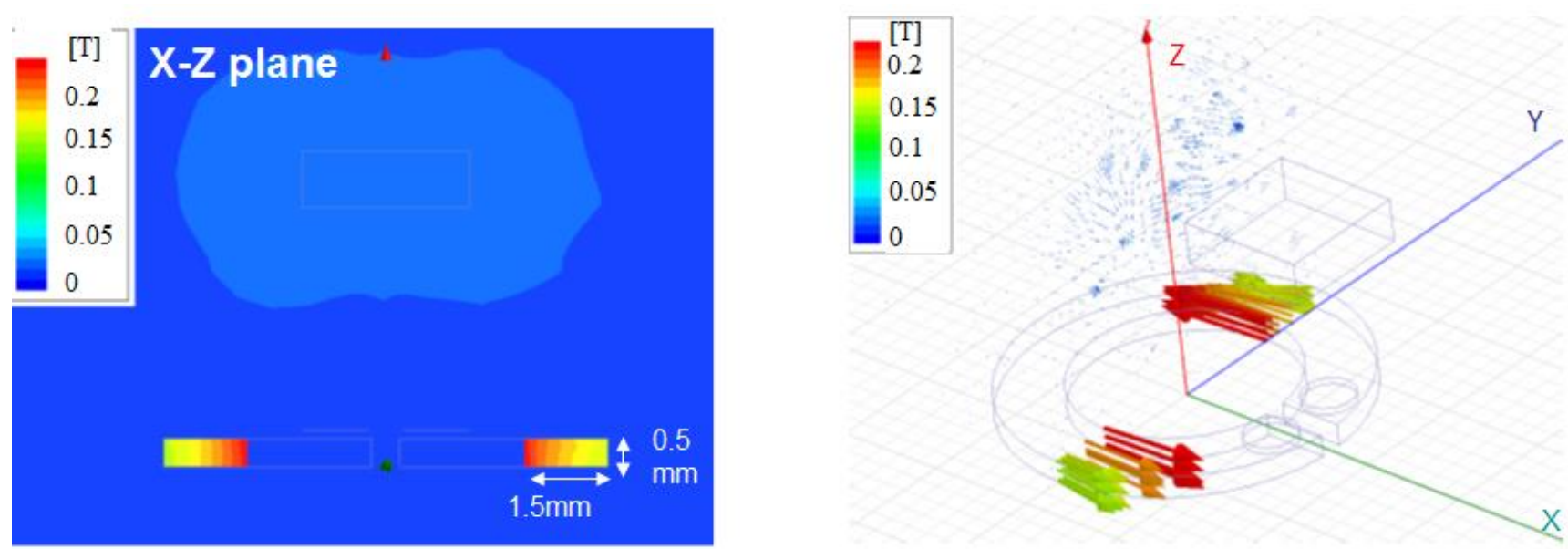

(b) The distance between magnetic material and magnet is $4 \mathrm{~mm}$.

Fig.5 The simulation result of magnetic flux density.

\section{4.＼cjkstart磁性体内臓の積層基板型コイルの試作および検証}

熱可塑性樹脂基板を積層し且つ磁性体部品を内蔵した，積層基板型の小型コイルを試作した．図 6 に小型コイ ル試作品の写真および内部構造を示す.試作した積層基板型コイルの外形サイズは $18 \mathrm{~mm} \times 18 \mathrm{~mm}$, 厚み $2 \mathrm{~mm}$ とした. 内部のコイルは放射状の配線パターンと厚み方向に接続するビアから形成される積層基板構造型のコイルとし， 巻き数 30 ターンで形成した. さらにそのコイルの内部に配置されるように, 磁性体部品（アモルファスダスト, 飽和磁束密度 $1 \mathrm{~Wb} / \mathrm{m}^{2}$, 比透磁率 100 , 磁路幅 $\left.3.25 \mathrm{~mm} \times 1.5 \mathrm{~mm}\right)$ を内蔵実装した. アモルファスダストは, レーザ 一カットによりカット（カット幅は $1 \mathrm{~mm}$ ） したものをパターン加工した熱可塑性樹脂基板とともに積層し，一括 熱プレスによって内蔵実装した。

試作した積層基板型小型コイルにおいて, 磁石と磁性体との距離を外部振動によって変化させた時の出力を加 振器を用いた原理実験により評価した. 図 7 に実験構成を示す. ネオジ磁石を加振器に設置し, 加振機にて正弦 波振動を与えた時に, 試作品の磁性体と磁石との距離が変化し, 閉磁路と開磁路が切り替わる評価系を構築, 得 られるコイル出力を評価した，なお，正弦波振動を与えた際，磁石の変位がピーク時に磁石と試作品が接触する 位置関係となっている. 図 8 に出力結果を示す. 正弦波振動の周波数を $50 \mathrm{~Hz}$ とし, 磁石の変位量は印可 $\mathrm{G}$ の大き さを 5〜20G まで変化させることで変えている. 上記磁石の変位量に対する出力電圧をプロットしており, 変位量 の増大に対して出力電圧も増大している. 但し, 出力電圧の増加は変位量に対して線形ではないが, これは, 磁 
石と磁性体の距離に対して, 磁性体内部の磁束密度の減少が線形ではないため（図 4) と考える. 磁石と磁性体 の距離が 0 4mm まで変化がする振動条件 (50Hz で 20G) において, 出力電圧 $13 \mathrm{mV}$ を得た。 これは, 磁性体内部の 磁束密度の変化を0.9T (シミュレーション結果より, 磁石と磁性体の距離 $4 \mathrm{~mm}$ の変化で磁束密度 $1 \mathrm{~T}$ が $0.1 \mathrm{~T}$ まで 減少する), 磁束が通る磁性体断面積 $3.25 \mathrm{~mm} \times 1.5 \mathrm{~mm}$ ，コイル巻き数 30 ターン, 正弦波周波数 $50 \mathrm{~Hz}$ から理論計算 したコイルの起電力 $13 \mathrm{mV}$ と一致するため, 外部振動から効率よく出力が得られていることを検証できた.
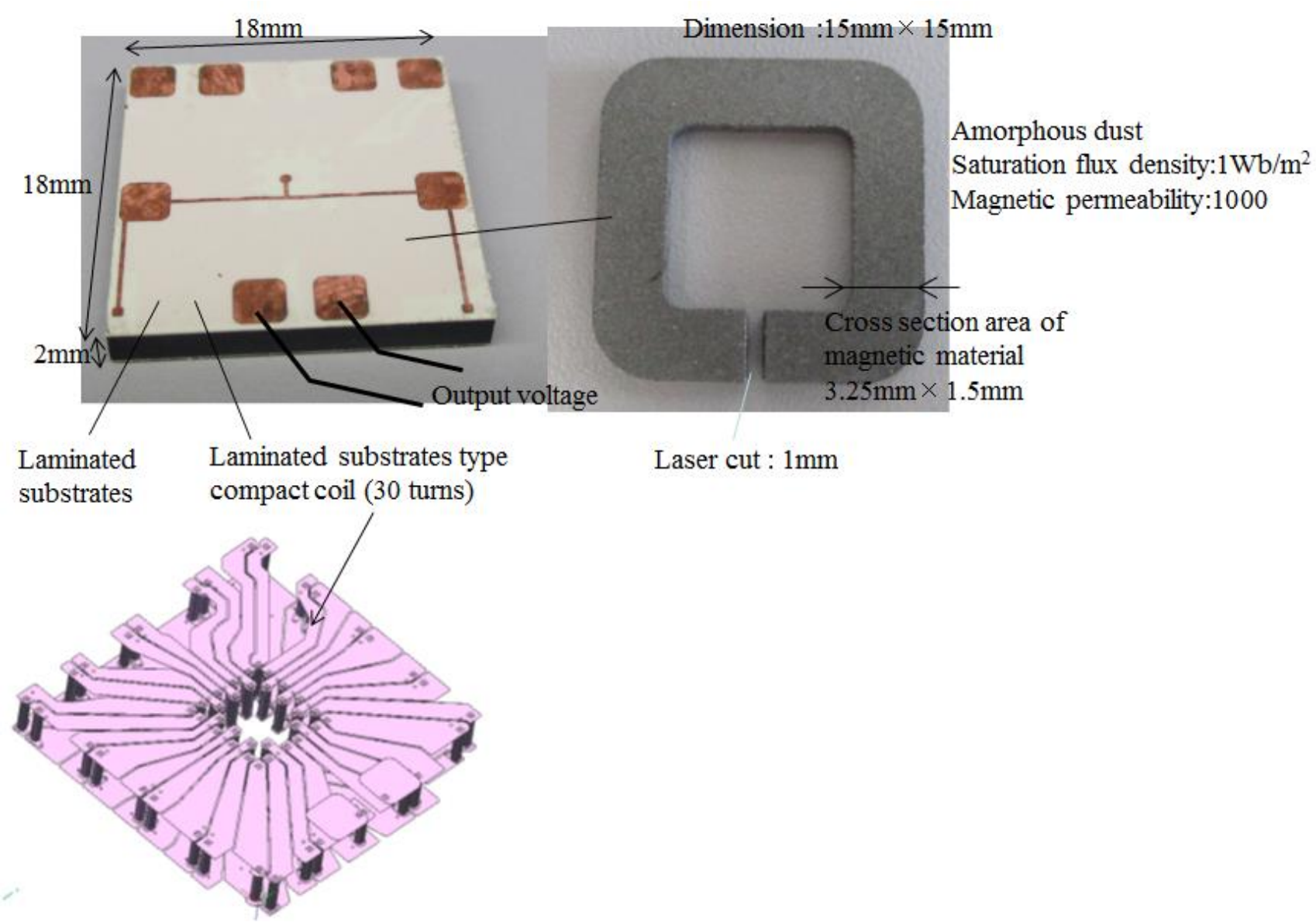

Laser cut : $1 \mathrm{~mm}$

substrates compact coil (30 turns)

Fig.6 The structure of laminated substrate type compact coil.

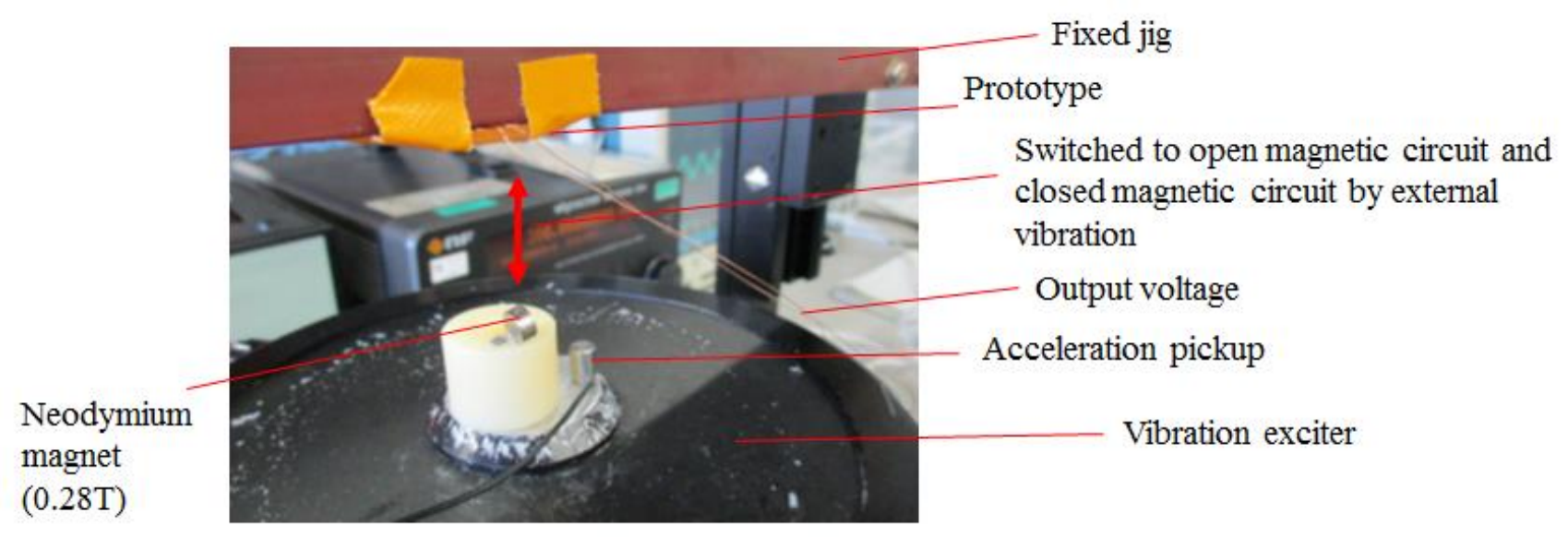

Fig.7 The evaluation composition of output power of compact coil. 


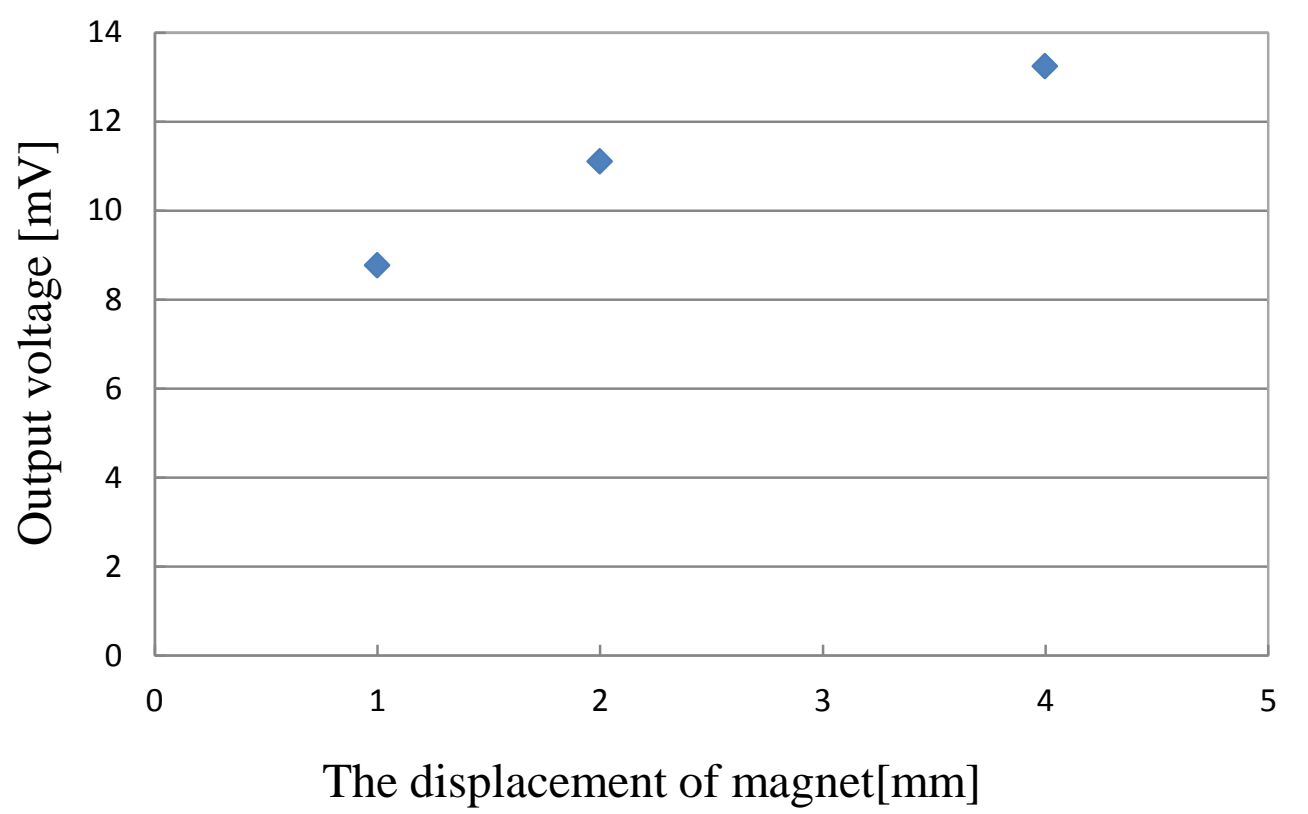

Fig. 8 The output voltage of prototype.

さらに, 積層基板型コイル試作品を適用し, 磁石が外部振動によって振動する振動梁と組み合わせた電磁誘導 式発電素子を試作した。この試作品を用いて，次世代タイヤ空気圧モニタ（より細かなセンシングの実現を狙っ た，タイヤのトレッド裏面に搭載するタイプ）の電源への適用を想定し, 発電量を検証した. 図 9 に試作品の写 真および評価系を示す. 発電素子試作品を加振器に設置し, 加振器にタイヤ振動を模擬した振動を入力, 試作品 での出力電圧を評価した (オシロの $1 \mathrm{M} \Omega$ で受けた電圧を計測)．タイヤ振動を模擬した振動は，タイヤのトレッド 裏面に計測用の市販 Gセンサ (B\&K 社製)を接着搭載し，実車走行において取得した振動データを入力している. なお，振動データは市販車両および市販タイヤを用い, 舗装アスファルト路を $20 \mathrm{~km} / \mathrm{h}$ で走行した時のタイヤ回転 方向の振動データである. 振動波形にみられるパルスは, タイヤ 1 回転に 1 回, G センサが路面に接地するとき に発生（接地開始時に G センサが円周運動から直線運動に変化することで発生，また接地終了時に G センサが直 線運動から円周運動に変化することで発生）している.

図 10 に発電素子試作品の出力評価結果を示す，試作品の出力電圧波形および，整合負荷 $(1 \Omega)$ に供給した時の 電力を出力電圧值より計算した結果を示している. 負荷抵抗での出力はコイルで発生した電圧がコイル側のイン ピーダンスと負荷抵抗で分圧された值として取り出せる. 発電素子のコイル側のインピーダンスは $1 \Omega$ (インピ ーダンスアナライザでの計測值）であり，1 $\Omega$ (整合抵抗）で受けた電圧は，オシロで計測した（1M $\Omega$ で受けた） 電圧に対して $1 / 2$ になる. なお, 整合負荷で受けているため, 発電素子のコイル側に流れる電流はないものと考 える. 図 10 の発生電力は, 上記計算より求めた電力を示している. タイヤ 1 回転で約 $0.5 \mu \mathrm{J}(=$ 約 $1.7 \mu \mathrm{W}), 1$ 分 で約 $100 \mu \mathrm{J}$ （タイヤ空気圧モニタシステムの無線機を動作するためのエネルギー）を蓄電できることが検証でき た. 


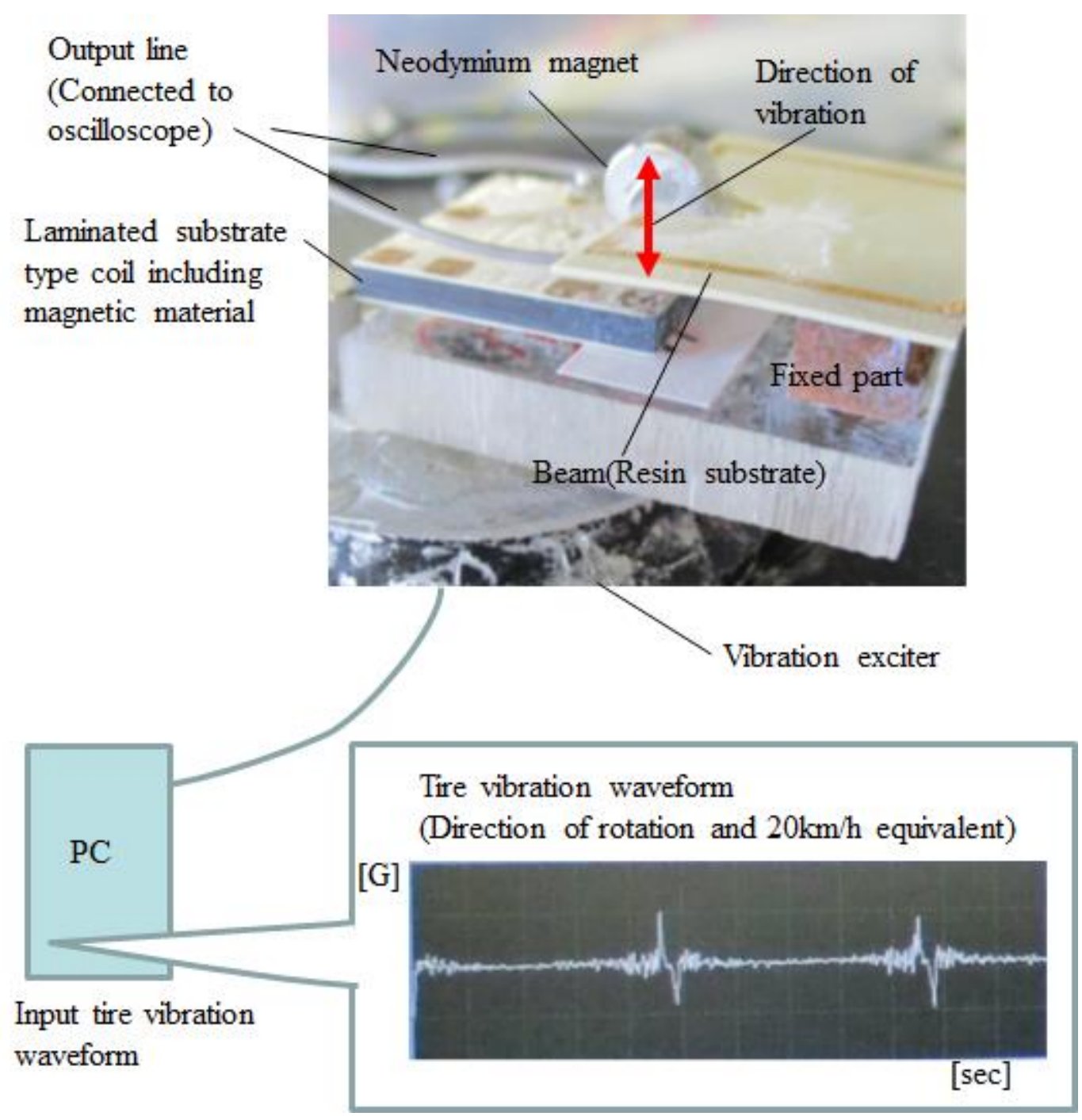

Fig. 9 Prototype of electromagnetic induction type energy harvester and evaluation composition.

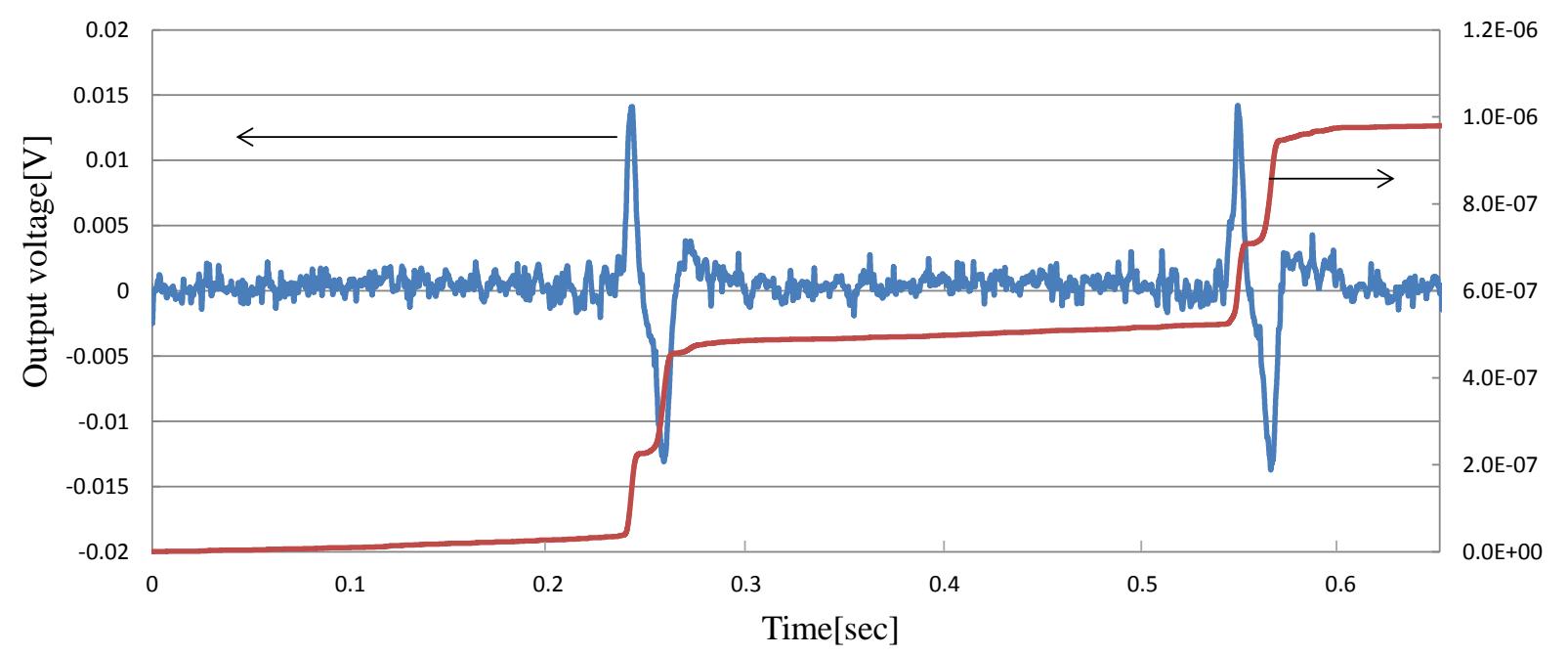

Fig. 10 Evaluation result of prototype of electromagnetic induction type energy harvester. 


\section{5. 結 言}

本研究では，車両搭載用の小型エネルギーハーベスタとして，電磁誘導式発電素子の小型化を目指した．小型 化でネックとなるコイル部において，熱可塑性樹脂でできた極薄基板を用いた積層基板構造によりコイルを形成 し，さらに部品内蔵実装の特長を生かして，コイル内部に磁性体部品を内蔵した小型コイルを提案，サンプル試 作した. 外部振動により磁石と磁性体の距離が変化することで, 積層基板型コイル内部を通る磁束を変化させ, 起電力を得る素子構造を試作し，加振機での原理検証および，タイヤ内部への搭載を想定したタイヤ振動模擬実 験を実施した, $20 \mathrm{~km} / \mathrm{h}$ 走行相当の振動から約 $1.7 \mu \mathrm{W}$ の出力が得られ, タイヤ空気圧モニタの電源として適用可 能なレベル（無線機を約 1 分に 1 回動作可能なレベル）であることを検証した.

\section{文 献}

花塚泰史，樋口知之，松井知子，HMM に基づくタイヤ振動波形解析による路面状態判別，電子情報通信学会論 文誌, Vol.J95-D, No.3(2012), pp.570-577.

Hayashi, A., Nakagoshi, M., Murai, T., Sera, N., Ogihara, C., Oikawa, R., Suzuki, K., Kataoka, R. and Ozaki, Y., A new FCBGA packaging technology based on the PALAP process, The $7^{\text {th }}$ VLSI Packaging Workshop of Japan, Session 5.3( 2004).

片岡良平，近藤宏司，鈴木克信，PALAP 基板による半導体パッケージ技術の開発，デンソーテクニカルレビュ 一, Vol.10, No.2 (2005), pp.77-84.

Morinaga, H., Hanatsuka, Y. and Wakao, Y., Sensing technology tire system for road surface condition judgment, FISITA2010 Transactions, Vol.F2010E010 (2010), pp.1-8.

Morinaga, H., Wakao, Y., Hanatsuka, Y. and Kobayakawa, A., The possibility of intelligent tire (technology of contact area information sensing), FISITA2006 Transactions, Vol. F2006V104(2006), pp.1-11.

鈴木洋一朗, 河野秀一，片岡良平，木村友則，桑野博喜，積層基板構造による小型広帯域コイルの検討，日本機 械学会論文集, Vol.81, No.828(2015), DOI：10.1299/transjsme.14-00696.

矢崎芳太郎，横地智宏，片岡良平，近藤宏司，鈴木克信，固層拡散接合を適用した PALAP 多層基板の開発，デ ンソーテクニカルレビュー, Vol.10, No.2(2005), pp.85-89.

\section{References}

Hanatsuka, Y., Higuchi, T. and Matsui, T., Classification of road-surface condition by tire acceleration waveform analysis based on HMM, IEICE Transactions on Information and Systems, Vol.J95-D, No.3(2012), pp.570-577(in Japanese).

Hayashi, A., Nakagoshi, M., Murai, T., Sera, N., Ogihara, C., Oikawa, R., Suzuki, K., Kataoka, R. and Ozaki, Y., A new FCBGA packaging technology based on the PALAP process, The $7^{\text {th }}$ VLSI Packaging Workshop of Japan, Session 5.3(2004).

Kataoka, R., Kondo, K. and Suzuki, K., Semiconductor packaging technology based on the PALAP process, Denso technical review, Vol.10, No.2 (2005), pp.77-84 (in Japanese).

Morinaga, H., Hanatsuka, Y. and Wakao, Y., Sensing technology tire system for road surface condition judgment, FISITA2010 Transactions, Vol.F2010E010 (2010), pp.1-8.

Morinaga, H., Wakao, Y., Hanatsuka, Y. and Kobayakawa, A., The possibility of intelligent tire (technology of contact area information sensing), FISITA2006 Transactions, Vol. F2006V104(2006), pp.1-11.

Suzuki, Y., Kouno, S., Kataoka, R., Kimura, T. and Kuwano, H., Study of compact and broad spectrum coil by the laminated substrates structure, Transactions of the JSME(in Japanese), Vol.81, No.828(2015), DOI : 10.1299/transjsme.14-00696.

Yazaki, Y., Yokochi, T., Kataoka, R., Kondo, K. and Suzuki, K., A new Sn/Ag sintering alloy diffusion bonding technology for the PALAP. process, Denso technical review, Vol.10, No.2 (2005), pp.85-89 (in Japanese). 